\title{
Dividend Behaviour of Indian Companies Under Monetary Policy Restrictions
}

\author{
I. M. Pandey \\ Professor \\ Indian Institute of Management Ahmedabad
}

Ramesh Bhat

Professor

Indian Institute of Management Ahmedabad

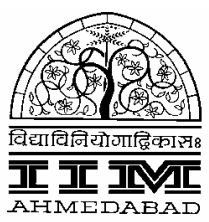

Indian Institute of Management

Ahmedabad

May 2004 


\title{
Dividend Behaviour of Indian Companies Under Monetary Policy Restrictions ${ }^{1}$
}

\begin{abstract}
In this study we examine the dividend behaviour of Indian companies. We use GMM estimator, which is the most suitable methodology in a dynamic setting. Our results show that the Indian firms have lower target ratios and higher adjustment factors. The most significant result is that the restricted monetary policies have significant influence on the dividend behaviour of Indian firms, causing about 5-6 percent reduction in the payout ratios. The significance of macro economic policy variable suggest that monetary policy restrictions do have impact on cost of raising funds, and the information asymmetry between lenders and borrowers increases that forces companies to reduce their dividend payout.
\end{abstract}

Key Words: Lintner's model; payout; information asymmetry; agency problems; signalling; GMM.

${ }^{1}$ The authors acknowledge the research assistance provided by Ms. Sujata Bachhawat in completing this study. 


\section{Dividend Behaviour of Indian Companies Under Monetary Policy Restrictions}

$\prod$ he study of corporate dividend behaviour has been a key research area in finance. Yet we still do not have an acceptable explanation for the observed dividend behaviour of companies and the 'dividend puzzle' still remains unsolved (Black, 1976). Under the assumption that capital markets are perfect, the finance researchers have shown that dividends are irrelevant, and that they have no influence on the share price (Miller and Modigliani, 1961). When capital markets are imperfect, some researchers have argued that dividends do matter and firms pursue an appropriate dividend policy. Several empirical surveys indicate that both managers and investors favour payment of dividends. Lintner (1956) was the first to point out that US companies distributed a large part of their earnings as dividends, and they also attempted to maintain stability of dividend. These findings have been vindicated in different countries and in different time periods.

The focus of this research is to examine the dividend behaviour of the listed firms in India - an emerging market in Asia. In emerging markets, including India, the central banks frequently use monetary policies as a control mechanism. Sometimes they follow highly restrictive policies, which affect the liquidity position in the economy. Hence in this study, we focus on the impact of the restricted monetary policy on the dividend policies of Indian firms. This study provides evidence that the listed Indian firms follow less stable dividend policies and their dividend payments are significantly affected by the restricted monetary policy of the government. To our knowledge this is a first study providing evidence of the restricted monetary policy constraining the dividend policies of firms in India.

The organisation of the article is as follows. The next section reviews some important previous studies abroad and in India. The third section describes the model and methodology and in the fourth section, we discuss the sample and data. In the fifth 
section, we present results and the last section contains the main conclusions of the study.

\section{Literature review}

Here we briefly focus on the empirical studies that deal with the dividend paying behaviour of firms. Lintner (1956) uncovered for the first time that firms in USA maintained a target dividend payout ratio and adjusted their dividend policy to this target. The long-term sustainable investment and growth objectives determined the firms' target payout ratios. Further, Lintner found that firms pursued a stable dividend policy and gradually increased dividends given the target payout ratio. This implies that firms set speed to move towards the full achievement of payout. These findings suggest that firms establish their dividends in accordance with the level of current earnings as well as dividend of the previous year. Lintner also pointed out that managers believe that investors prefer firms with stable dividend policies.

A number of surveys and empirical studies have been conducted in USA and other countries using Lintner's framework. In USA, Darling (1957), Fama and Babiak (1968), and Brittain (1966) use modified and extended Lintner model to confirm his findings. A survey of the NYSE-listed companies by Baker et. al. (1985) support the Lintner findings, and they conclude that the major determinants of dividend payments are future earnings and past dividends. The subsequent survey study of Pruitt and Gitman (1991) also confirms these results.

Lintner's model has been generally found applicable in a number of other developed markets. It has been tested by Chateau (1979) in Canada, Shevin (1982) in Australia, McDonald et. al. (1975) in France, Leithner and Zimmermann (1993) in West Germany, UK, France and Switzerland and Lasfer (1996) in UK. Dewenter and Warther (1998) compare dividend policies of firms in USA and Japan for the period from 1982 to 1993. Their results show that U.S.A firms tend to choose stable dividend policies whereas Japanese firms prefer to omit dividend and follow relatively unstable dividend policies. 
Researchers have recently started looking at the dividend behaviour of companies in regulated and emerging markets. Glen et. al. (1995) find substantial differences in dividend policies of companies in developed and emerging markets. They show that dividend payments are much lower in emerging markets, and firms follow less stable dividend policies, although they do have target payout ratios.

Ariff and Johnson (1994) confirm Lintner's model for firms in Singapore. In Turkey, Adaoglu (2000) finds that current earnings are the main determinant of dividend payments. After deregulation of distribution of profits in Turkey in 1994, when firms were given the flexibility of choosing their own dividend policy, they followed unstable dividend policies. A study of the dividend behaviour the listed Malaysian companies (Pandey, 2003) shows that payout ratios vary across industries and time. The results also reveal that the dividend behaviour of the Malaysian companies is sensitive to the changes in earnings. Further, using Lintner's framework and panel regression methodology, the study finds evidence of less stable dividend policies being pursued by the Malaysian companies. The results of the two-way fixed effects model reveal strong individual firm and time effects.

In India several studies have been conducted using the Lintner framework. A study by Bhat and Pandey (1994) in India supports the Lintner findings and reveals that Indian managers confirm that companies maintain an uninterrupted record of dividend payments and also try to avoid abrupt changes in their dividend policies.

What are the explanations for the firms' dividend payment behaviour? There are several explanations, but three most important include: agency problem and corporate control, signalling and tax. Dividend payments potentially mitigate agency problems (Easterbrook, 1984; Jensen, 1986). From the point of view of the corporate governance and control, dividend payments may be customised to attract large institutional investors who can effectively monitor the corporate governance (Shleifer and Vishny, 1986; Allen, Bernardo and Welch, 2000). The signalling explanation based on the asymmetric information implies that steady dividend payments provide signal about the firm's performance that is not conveyed by the financial reports and other disclosures. 
The prediction under the signalling hypothesis is the same as under the corporate control. Finally, the taxes might influence dividends paying behaviour of firms. Under current Indian law, individual shareholders do not pay any tax on dividend incomes, while they are taxed for realised capital gains. Instead of the investors, companies have to pay tax on the distributed incomes. This raises the effective corporate tax rates for the dividend paying companies. Thus the current tax laws may encourage dividend payments. However, this has not always been the case in India. In the past, dividends were taxed at the marginal personal tax rates. The essential point is that the high taxes on individuals' dividend income may discourage the payment of dividends.

\section{Model and methodology}

The Lintner dividend model has been most often used as an empirical framework to describe the determinants of dividend payment behaviour of firms. We also follow the Lintner framework. However, in this study our main motivation is to find out the dividend paying behaviour of Indian firms subject to the monetary policy restrictions. What is the relationship between the dividends and the restricted monetary policies?

We shall draw from Oliner and Rudebusch (1996) to show the implications of the monetary policy restrictions on the dividend payout policy. In Figure $1, F$ is the amount of internal funds and $S_{1}$ is its cost of funds schedule. The cost of these internal funds is a risk-adjusted cost including a risk-free rate $\left(\gamma_{f}\right)$ - an outcome of monetary policy variables and common for all firms and risk premium $(\varphi)$ - risk adjusted for the company under consideration. Under perfect capital markets, the cost of internal and external funds would be the same; that is, $r_{1}$ rate. However, when markets are not perfect, there are more chances of a firm defaulting on its debt due to moral hazard problem resulting from information asymmetry between borrowers and lenders. Hence $S_{1}$ rises beyond $F$ - the internal funds. The upward shift in the curve is also caused by the changes in risk-free rate caused by the monetary policy changes. This would reduce the value of the borrower's collateral, and consequently, increase moral hazard problem (Oliner and Rudebusch, 1996). Thus, there is a linkage between the risk premium and the macro-economic policies. Hence, this leads to shift in the schedule from $S_{1}$ to $S_{2}$. 


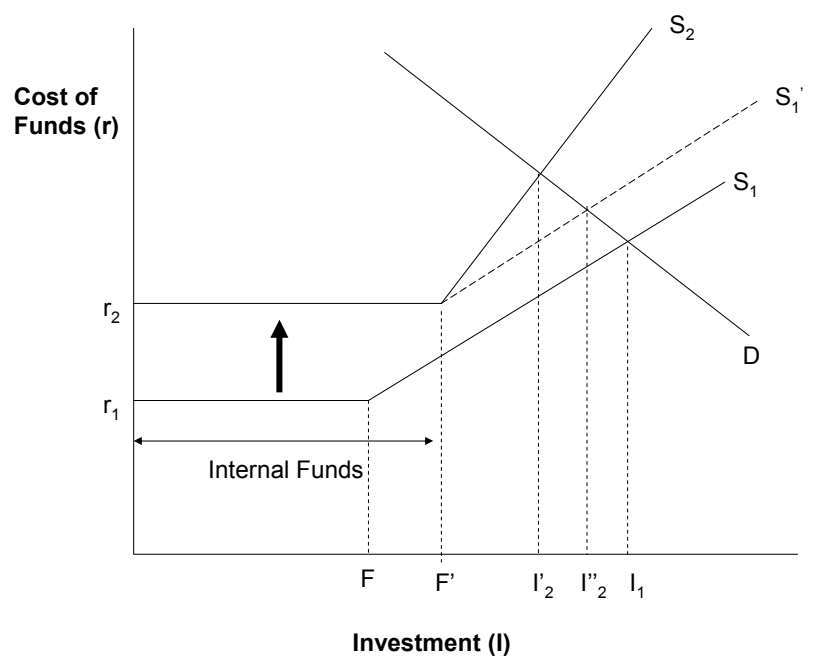

Figure 1 (Adapted from Oliner and Rudebusch, 1996)

After the monetary policy restrictions, the cost of external finances relative to internal funds increases. This shift in relative finance costs would cause shifts in investments. The amount of investments would be subject to the availability of internal funds and would be sensitive to such changes after monetary policy restrictions. As a result, in order to ensure availability of cheaper internal funds firms may first alter their dividend payout before raising the external funds. Under capital market imperfections, the effect of restrictive monetary policy would be significant under monetary tightening than during normal times. There would be shift in availability from $F$ to $F^{\prime}$ thereby increasing availability of funds from $I_{2}$ to $I^{\prime \prime}{ }_{2}$. This rise in cost of funds would have implications for the investments that fall from $I_{1}$ to $I_{2}$. Capital market imperfections magnify any macroeconomic shocks that affect borrowers' moral hazard (Stiglitz 1992). This is the reason why new supply schedule is $S_{2}$ and not $S^{\prime}{ }_{1}$. The restrictive monetary policy intensifies the effect on the cost of debt and external financing by pushing it up and increasing the spread at various levels of financial requirements.

Given the implications of monetary policy restrictions on availability of funds to meet firm's requirements, we expand the Lintner framework to examine the impact of these restrictions on dividend policy of companies. Our hypothesis is that during the monetary policy restrictions the dividend payout policy of firms change and the 
payouts are less. Desai, Foley and Hines (2002), based on the Lintner model, provide a useful framework for analysing the dividend paying behaviour of firms. This framework explicitly accounts for the cost of deviating from the target payout ratio and the cost of deviating from the previous year's dividend. In this framework, the target payout is likely to be a function of the macro-economic policy. From the basic Lintner model, Desai, Foley and Hines (2002) derive the following equation:

$$
\psi=\gamma_{1}\left(D_{i t}-k_{i t} E_{i t}\right)^{2}+\gamma_{2}\left(D_{i t}-D_{i t-1}\right)^{2}
$$

In this equation, $\Psi$ is the total cost of paying dividend, $k_{i t}$ is the target payout ratio and $E_{i t}$ is the earnings in period $\mathrm{t}, D_{i t}$ is dividend paid in period $t$ and $\mathrm{D}_{\mathrm{it}-1}$ is dividend paid in the past year. The aim of a firm should be to minimise $\Psi$ in deciding its dividend policy. Notice that the above specification is quadratic. This implies that the costs of paying dividend are symmetric around earnings and previous period's dividends and $\gamma_{1}$ and $\gamma_{2}$ both are greater than 0 .

We are not aware of any study that examines the impact of macro-economic variables on the dividend payout $\left(k_{i t}\right)$. As argued above, the dividend payout influences a firm's financing; hence the macro-economic variables such as interest rate or cost of capital would be relevant. The impact of the macro-economic variables may assume greater significance in the presence of information asymmetry between borrowers and lenders. In the presence of information asymmetry lenders incur costs in evaluating projects, and monitoring and enforcing outcomes. Hence, to compensate for these costs, providers of all types of external finance charge some premium over the cost of finance in comparison to the cost of internal funds (Gertler 1988). To describe these relationships through Lintner model, the loss function is minimised with respect to $D_{t}$ and we get the following:

$$
\mathbf{D}_{\text {it }}=\frac{\gamma_{1}}{\left(\gamma_{1}+\gamma_{2}\right)} \mathbf{k}_{\mathrm{it}} \mathbf{E}_{\mathrm{it}}+\frac{\gamma_{2}}{\left(\gamma_{1}+\gamma_{2}\right)} \mathbf{D}_{\mathrm{it}-\mathbf{1}}
$$

The parameters $\left[\gamma_{1} / \gamma_{1}+\gamma_{2}\right]$ in above equation depict the speed of adjustment. Since the coefficients of $k_{i t} E_{i t}$ and $D_{i t-1}$ are constrained to sum to one it is possible to estimate the 
value of $k_{i t}$. While estimating the model, we also release the constraint restricting the influence of past dividends to only one lag and extend estimations to two lags as suggested in Lehmann and Mody (2004). They also suggest considering the possibility of asymmetric response of dividends to positive and negative income changes. When there is positive movement in earnings, there is more flexibility with the managers to increase dividends whereas the same is not the case when earnings decline. In that case the equation becomes:

$$
\mathbf{D}_{\mathrm{it}}=\frac{\gamma_{1}}{\left(\gamma_{1}+\gamma_{2}\right)} \mathbf{k}_{\mathrm{it}} \mathbf{E}_{\mathrm{it}}^{+}+\frac{\gamma_{1}}{\left(\gamma_{1}+\gamma_{2}\right)} \mathbf{k}_{\mathrm{it}} \mathbf{E}_{\mathrm{it}}^{-}+\frac{\gamma_{2}}{\left(\gamma_{1}+\gamma_{2}\right)} \alpha \mathbf{D}_{\mathrm{it}-1}+\frac{\gamma_{2}}{\left(\gamma_{1}+\gamma_{2}\right)} \beta \mathbf{D}_{\mathrm{it}-2}
$$

In above equation $E^{+}$is earnings that have increased compared to that in the last period, with $E$ equal to zero in that period and conversely for $E$. Further, $\alpha$ and $\beta$ are the weights accorded respectively to the first and second lag of dividends and add up to one.

Finally, we consider the impact of monetary restriction in the above specifications [Equation (3)]. We use dummy variable to represent the monetary restriction (MR). $\mathrm{MR}_{\mathrm{t}}$ is dummy variable assuming value 1 in monetary restricted year and 0 when there is no monetary restriction. Thus, our empirical model is as follows:

$$
\begin{aligned}
\mathbf{D}_{\mathrm{it}}= & \lambda_{0}+\lambda_{1} \mathbf{E}_{\mathrm{it}}+\lambda_{2} \mathbf{D}_{\mathrm{it}-1}+\lambda_{3} \mathbf{D}_{\mathrm{it}-2}+\lambda_{4} \mathbf{M R}_{\mathrm{t}} * \mathbf{D}_{\mathrm{it}-1} \\
& +\lambda_{5} \mathbf{M R}_{\mathrm{t}} * \mathbf{D}_{\mathrm{it}-2}+\varphi_{\mathrm{i}}+\phi_{\mathrm{t}}+\varepsilon_{\mathrm{it}}
\end{aligned}
$$

The impact of monetary restriction on dividend payout can be worked out in the following manner:

Dividend payout in normal year: $\mathrm{k}_{\mathrm{t}}=\lambda_{1} /\left(1-\lambda_{2}-\lambda_{3}\right)$

Dividend payout in restricted year: $\mathrm{k}_{\mathrm{t}}=\lambda_{1} /\left(1-\lambda_{2}-\lambda_{3}-\lambda_{4}-\lambda_{5}\right)$

Our estimation model [Equation (4)] uses panel data. Panel data, unlike cross-section or time series data, allows controlling for unobservable heterogeneity through individual (firm) effect $\left(\varphi_{\mathrm{i}}\right)$. We also include dummies for time variable to measure temporal effect $\left(\phi_{t}\right)$. This helps in controlling the general effect of all other macro-economic variables. 
Pooling of time-series cross-sectional data provides more observations, more variability, less collinearity among variables, more degree of freedom and more efficiency (Baltagi, 1995, p. 3-6). More importantly, pooled data are more proficient to identify and measure effects that are undetectable in pure cross-section or pure time-series data. Moreover, the measurement biases resulting from aggregation over firms or individuals and biases arising from omitted-variables are reduced (Pindyck and Rubinfeld, 1998, p.250). The merit of a panel data over cross-section data is the ease of modelling the differences in behaviour across individuals (Greene 2003). Moreover, it is only through the panel data analysis it is possible to examine the effect of monetary policy restrictions of several years and the dynamics of change in dividend payouts effectively.

\section{Sample and data}

The source of the data used in the study is the CMIE (Centre for the Monitoring of the Indian Economy) Prowess database. The sample includes all firms in the manufacturing sector for which the annualised data for all the years starting from 1989 to 1997 were available. We have restricted our sample until the year 1997 because of the relative consistency of the tax policy with regard to dividends and capital gains. After 1997, there was substantial change in the policy of taxing dividends and capital gains. Hence, to avoid the estimation complication of the unknown bias, we have not considered years beyond 1997. Further, in order to avoid the bias arising from the very small firms in the sample, we excluded the firms for which the average net sales for the sample period were less than Rs. 100 million. We also excluded firms with missing data for two or more consecutive years, with negative net worth and those without the dividend information up to two lag periods. Our final sample consists of data for 571 firms. We have constructed a balanced data panel of the Indian firms. In our estimations, we used lags of dividends up to two periods. Thus our panel observations are 3997. Data for all firms with accounting year ending from any month during October to September have been considered as the data falling in one-year category.

In estimation models, variables include dividends, earnings and an interaction variable equal to the product of monetary restriction (MR) and lagged dividends. MR is a 
dummy variable; in periods of restrictive monetary policy, MR assumes a value of one, otherwise zero. Our dependent variable is dividends in the current year $\left(\mathrm{D}_{\mathrm{t}}\right)$. Earnings $\left(E_{t}\right)$ are net profits after taxes. $E^{+}$(earnings plus) denotes earnings that have increased over that in the previous period and $\mathrm{E}^{-}$(earnings minus) in that period will be zero. And in the same way, $\mathrm{E}^{-}$denotes earnings that have decreased over that in the previous period with $\mathrm{E}^{+}$equal to zero in that period. It is difficult to clearly identify the stance of monetary policy with a single indicator. Hence, we didn't use bank rate, lending rate, or the interest rate spreads as parameters for identifying the restrictive policy years. Instead, we used the Reserve Bank of India's Economic Survey Reports as a base to identify the restrictive years. Beginning from 1991 to 2002, only two years could be clearly identified as restrictive years. They are years 1991-92 and 1996-97. For example, the Economic Survey of 1992 states that the stance of monetary policy in 1991-92 was highly restrictive in order to contain the growth of aggregate demand to fight the twin problems of high inflation and adverse balance of payments. Further, the Economic Survey states that during 1996-1997 the bank lending rates remained sticky for sometime despite the increased liquidity with the banks following cash credit ratio (CRR) reductions. Banks did not reduce interest rates immediately in order to avoid a dent in the interest rate spread that would have affected profits adversely. With inflation falling sharply, real interest rates rose, contributing to lower demand for credit. Though nominal interest rates fell during the 1996-97 period, real interest rates rose during this period because of falling inflation rates.

\section{Results}

Table 1 provides summary statistics (mean, standard deviation, maximum and minimum) of earnings and dividends and mean payout ratios. Both mean earnings and dividends have increased over years. The standard deviations have also risen. The gaps between minimum and maximum earnings are quite large; the minimum earrings are negative in each year. The average payout, except for two-three years, has varied within a narrow range. 
Table 1: Descriptive Statistics

\begin{tabular}{|c|c|c|c|c|c|c|c|c|c|}
\hline & \multicolumn{4}{|c|}{ Earnings (Rs. in millions) } & \multicolumn{4}{|c|}{ Dividends (Rs. in millions) } & \multirow{2}{*}{$\begin{array}{c}\text { Payout } \\
(\%)\end{array}$} \\
\hline Year & Mean & Stdev & $\operatorname{Max}$ & Min & Mean & Stdev & $\operatorname{Max}$ & Min & \\
\hline 1989 & 37 & 114 & 1549 & -340 & 13 & 41 & 609 & 0 & 36 \\
\hline 1990 & 52 & 127 & 1185 & -187 & 17 & 47 & 506 & 0 & 34 \\
\hline 1991 & 65 & 155 & 1513 & -180 & 21 & 57 & 713 & 0 & 33 \\
\hline 1992 & 72 & 191 & 2090 & -359 & 25 & 68 & 806 & 0 & 34 \\
\hline 1993 & 65 & 211 & 3194 & -576 & 29 & 80 & 848 & 0 & 44 \\
\hline 1994 & 107 & 312 & 5052 & -374 & 40 & 113 & 1384 & 0 & 38 \\
\hline 1995 & 189 & 607 & 10086 & -292 & 56 & 157 & 1993 & 0 & 30 \\
\hline 1996 & 250 & 836 & 12809 & -578 & 68 & 201 & 2762 & 0 & 27 \\
\hline 1997 & 223 & 846 & 12797 & -1464 & 71 & 233 & 2992 & 0 & 32 \\
\hline All & 118 & 479 & 12809 & -1464 & 38 & 131 & 2992 & $\overline{0}$ & 32 \\
\hline
\end{tabular}

Table 2 displays the results of the two-way fixed effects models. We have estimated four models. Model 1 includes current earnings, lagged dividend and monetary restrictions interaction variables as independent variables. Model 3 has $t-1$ and $t-2$ lagged dividends and the associated monetary restriction interaction variable as additional independent variables. Models 2 and 4 introduce positive and negative movements in earnings as independent variables.

Table 2: Two-way Fixed Effects Model

\begin{tabular}{|c|c|c|c|c|c|c|c|c|}
\hline & \multicolumn{2}{|c|}{ Model 1} & \multicolumn{2}{|c|}{ Model 2} & \multicolumn{2}{|c|}{ Model 3} & \multicolumn{2}{|c|}{ Model 4} \\
\hline & Coef. & t-value & Coef. & t-value & Coef. & t-value & Coef. & t-value \\
\hline Constant & $0.527^{*}$ & 3.55 & $0.378^{*}$ & 3.71 & $0.734^{*}$ & 4.44 & $0.564^{*}$ & 4.03 \\
\hline $\mathrm{D}_{-1}$ & $0.720^{*}$ & 12.39 & $0.798^{*}$ & 16.07 & $0.707^{*}$ & 6.42 & $0.777^{*}$ & 7.85 \\
\hline $\mathrm{D}-2$ & & & & & -0.025 & -0.28 & -0.013 & -0.18 \\
\hline MR1 & -0.032 & -0.98 & $-0.085^{*}$ & -4.14 & $0.417^{*}$ & 2.07 & $0.365^{*}$ & 2.00 \\
\hline MR2 & & & & & $-0.632^{*}$ & -2.47 & $-0.623^{*}$ & -2.54 \\
\hline E & 0.092 & 18.94 & & & $0.089^{*}$ & 13.71 & & \\
\hline $\mathrm{E}^{-}$ & & & $0.057^{*}$ & 7.87 & & & $0.056^{*}$ & 5.29 \\
\hline$E^{+}$ & & & $0.093^{*}$ & 12.68 & & & $0.089^{*}$ & 11.3 \\
\hline Adj. $R^{2}$ & 0.946 & & 0.949 & & 0.950 & & 0.953 & \\
\hline F-statistic & $139.36^{*}$ & & $146.72^{*}$ & & $132.68^{*}$ & & $138.76^{*}$ & \\
\hline Hausman & $281.13^{*}$ & & $233.95^{*}$ & & $320.60^{*}$ & & $278.10^{*}$ & \\
\hline Payout & E & & $\mathrm{E}^{+}$ & $\mathrm{E}^{-}$ & $\mathrm{E}$ & & $\mathrm{E}^{+}$ & $\mathrm{E}^{-}$ \\
\hline Normal & $33 \%$ & & $46 \%$ & $28 \%$ & $28 \%$ & & $38 \%$ & $24 \%$ \\
\hline Restricted & $29 \%$ & & $32 \%$ & $20 \%$ & $17 \%$ & & $18 \%$ & $11 \%$ \\
\hline
\end{tabular}

1. $\mathrm{t}$-stats are White heteroskedasticity corrected estimates

2. Significant at $1 \%$ level of significance

3. Significant Hausman statistic rejects REM in favour of FEM 
The two-way fixed effects control for unobservable characteristics that might influence dividend policy. The Lintner specification fits the data quite well. The regression coefficients of current earnings, $\mathrm{E}_{\mathrm{t}}$ and lagged dividends, $\mathrm{D}_{\mathrm{t}-1}$ depict right signs and are statistically significant. The generally higher coefficients and the associated t-statistics of $\mathrm{D}_{\mathrm{t}-1}$ imply the greater importance of past dividend in deciding the dividend payment. The signs of coefficients of lagged dividends $\mathrm{D}_{\mathrm{t}-2}$ are negative, but they are not statistically significant. The estimated coefficients on lagged dividends in the four models range from 0.70 to 0.78 . This implies adjustment parameters ranging from 0.22 to 0.30 . The companies' desired payout ratio is given by the ratio of the estimated coefficient on earnings and the estimated adjustment parameter. Thus the desired payout ratios vary from 24 percent to 46 percent. The coefficients of the monetary restriction-lagged dividends interaction variables are statistically significant. The test for the possibility of asymmetric response of dividends to positive and negative movements in earnings shows that the increased earnings lead to increased dividend payout and the reduced earnings to lower dividend payments. The monetary restrictions have a much larger effect on payout ratios when we consider changes in earnings. The statistically significant Hausman statistic in all models favours the fixed effects model over the random effects model (REM).

The fixed effects estimator controls for unobservable heterogeneity. But the specification in Equation (4) is a dynamic model. A dynamic model with lagged dependent variable as independent variable causes considerable difficulty in estimation. The error term may be auto-correlated; but more seriously, the lagged dependent variable is correlated with the error term when we use fixed or random effects models (Greene, 2003). The literature has suggested the use of instrumental variables (IV) estimators and the generalized method of moments (GMM) estimator in estimation of dynamic models. Here to avoid the problems of heterogeneity and the biases caused by the lagged dependent variable, we use the GMM procedure based on Arellano and Bond (1991) and Arellano and Bover (1995). The GMM estimator uses instrument variables. In our estimations, we use as instruments all the right-hand side variables and their onelagged values. The results of the GMM estimator based on Arellano and Bover (1995) 
are given in Table 3. Estimation based on Arellano and Bover (1995) uses orthogonal deviations and it removes the individual effects.

Table 3 shows results of four estimation models. The estimated coefficients on lagged dividends in the four models vary from 0.21 to 0.31 . In Model 1 it is 0.29 . This implies that Indian companies pay dividends with adjustment parameters equal to $(1-0.29)=$ 0.71. The desired payout ratio is given by the ratio of the estimated coefficient on earnings (0.18) and the estimated adjustment parameter -the implied desired payout ratio is $(0.18 / 0.71)$, or 25 percent. The coefficient of the monetary restriction-lagged dividends interaction variable, $M R 1\left(\mathrm{MR}_{\mathrm{t}}^{*} \mathrm{D}_{\mathrm{t}-1}\right)$ appears with a negative sign and it is statistically significant. Hence, the monetary restriction-lagged dividends interaction variable causes reduction in dividend payments. The desired restricted payout ratio reduces by 3 percent to 22 percent. In Model 2, we test for the possibility of asymmetric response of dividends to increases and decreases in earnings. We do find some evidence of the positive earnings changes leading to increased dividend payout and the negative earnings leading to reduced dividend payments. The payout ratio is 26 percent when earrings changes are positive and 25 percent when they are negative. The monetary restrictions reduce payout by 3 percent both under positive and negative changes in earnings.

Table 3: Panel Generalized Method of Moments (Orthogonal Deviations)

\begin{tabular}{|c|c|c|c|c|c|c|c|c|}
\hline variables & coef. & t-stat & coef. & t-stat & coef. & t-stat & coef. & t-stat \\
\hline $\mathrm{D}_{-1}$ & $0.290^{*}$ & 23.91 & $0.311^{*}$ & 19.79 & $0.208^{*}$ & 14.21 & $0.220^{*}$ & 14.06 \\
\hline $\mathrm{D}_{-2}$ & & & & & 0.116 & 6.34 & $0.115^{*}$ & 6.32 \\
\hline MR1 & $-0.095^{*}$ & -15.46 & $-0.107^{*}$ & -16.29 & $0.307^{*}$ & 14.74 & $0.296^{*}$ & 13.62 \\
\hline MR2 & & & & & $-0.544^{*}$ & -19.76 & $-0.543^{*}$ & -18.64 \\
\hline $\mathrm{E}$ & $0.180^{*}$ & 38.68 & & & $0.171^{*}$ & 31.36 & & \\
\hline $\mathrm{E}^{-}$ & & & $0.182^{*}$ & 42.68 & & & $0.167^{*}$ & 21.58 \\
\hline$E^{+}$ & & & $0.172^{*}$ & 30.86 & & & $0.173^{*}$ & 28.59 \\
\hline $\mathrm{R}^{2}$ & 0.768 & & 0.771 & & 0.765 & & 0.766 & \\
\hline Adj. $R^{2}$ & 0.768 & & 0.771 & & 0.765 & & 0.766 & \\
\hline Sargan stat. & 37.22 & & 36.65 & & 31.95 & & 32.02 & \\
\hline p-value & 0.241 & & 0.223 & & 0.519 & & 0.231 & \\
\hline Observations & 3997 & & 3997 & & 3426 & & 3426 & \\
\hline & $\mathrm{E}$ & & $E^{+}$ & $\mathrm{E}^{-}$ & $\mathrm{E}$ & & $\mathrm{E}^{+}$ & $\mathrm{E}^{-}$ \\
\hline \multicolumn{9}{|l|}{ Payout } \\
\hline Normal & $25 \%$ & & $25 \%$ & $26 \%$ & $25 \%$ & & $26 \%$ & $25 \%$ \\
\hline Restricted & $22 \%$ & & $22 \%$ & $23 \%$ & $19 \%$ & & $19 \%$ & $18 \%$ \\
\hline
\end{tabular}


Notes:

1. t-stats are White heteroskedasticity corrected estimates

2. * Significant at $1 \%$ level of significance

3. The instruments include independent variables and one lagged values.

4. Sargan's statistic is a specification test of overidentifying restrictions, which tests for the absence of correlation between the instruments and the error term.

In Models 3 and 4 we release the constraint restricting the influence of past dividends to only one lag and extend the analysis to two lags. In Model 4, we also consider the asymmetric response of dividends to positive and negative changes in earnings. Though the coefficients of the two-year lagged dividends are statistically significant, yet the normal desired payout does not change. However, the monetary restrictions interacting with one-year lag and two-year lag dividends cause larger reduction in the desired payout ratios; the reduction is about 5-6 percent.

We also make estimations using model Arellano and Bond (1991). In Table 4, we present results based on the first differences method, as suggested by Arellano and Bond (1991). The results are very similar to the results obtained using Arellano and Bover (1995) model. Thus our methodology is robust and we obtain consistent results.

Overall, we find that there is strong evidence that Indian firms always consider dividend paid in the past two years as important benchmark for deciding the current dividend payment. Further, the high adjustment factors together with low payout ratios indicate that the Indian firms frequently change their dividend payments, and dividend smoothing is of a lower order. There is also evidence of the asymmetric response to dividends to increase and decrease in earnings; firms pay more dividends when their earnings increase. The most interesting finding of the study is that the restricted monetary policies cause reduction in dividend payments of Indian firms. The restricted monetary policies constrain the flow of funds in the economy that has its impact of the dividend paying behaviour of the firms.

Table 4: Panel Generalized Method of Moments (First Difference)

\begin{tabular}{lcccccccr}
\hline variables & coef. & t-stat & coef. & t-stat & coef. & t-stat & coef. & t-stat \\
\hline D-1 & $0.290^{*}$ & 23.50 & $0.319^{*}$ & 20.04 & $0.207^{*}$ & 14.64 & $0.226^{*}$ & 14.31 \\
D-2 & & & & & $0.125^{*}$ & 7.07 & $0.123^{*}$ & 6.90 \\
MR1 & $-0.094^{*}$ & -15.20 & $-0.111^{*}$ & -16.32 & $0.251^{*}$ & 10.76 & $0.238^{*}$ & 10.10
\end{tabular}




\begin{tabular}{|c|c|c|c|c|c|c|c|c|}
\hline MR2 & & & & & $-0.473^{*}$ & -16.13 & $-0.472^{*}$ & -15.65 \\
\hline $\begin{array}{l}E \\
E^{-}\end{array}$ & 0.183 & 38.73 & $0.184^{*}$ & 43.13 & & & $0.166^{*}$ & 23.72 \\
\hline$E^{+}$ & & & $0.171^{*}$ & 30.63 & & & $0.174^{*}$ & 32.09 \\
\hline $\mathrm{R}^{2}$ & 0.281 & & 0.268 & & 0.353 & & 0.343 & \\
\hline $\operatorname{Adj} . R^{2}$ & 0.281 & & 0.268 & & 0.352 & & 0.342 & \\
\hline J-stat & 37.18 & & 36.75 & & 32.42 & & 32.41 & \\
\hline p-value & 0.282 & & 0.220 & & 0.258 & & 0.212 & \\
\hline Observations & 3997 & & 3997 & & 3426 & & 3426 & \\
\hline Payout & E & & $\mathrm{E}^{+}$ & $\mathrm{E}^{-}$ & E & & $\mathrm{E}^{+}$ & $E^{-}$ \\
\hline Normal & $26 \%$ & & $25 \%$ & $27 \%$ & $26 \%$ & & $27 \%$ & $25 \%$ \\
\hline Restricted & $23 \%$ & & $22 \%$ & $23 \%$ & $19 \%$ & & $20 \%$ & $19 \%$ \\
\hline
\end{tabular}

1. t-stats are White heteroskedasticity corrected estimates

2. * Significant at $1 \%$ level of significance

3. The instruments include independent variables and one lagged values.

4. J-statistic is a specification test of overidentifying restrictions, which tests for the absence of correlation between the instruments and the error term.

\section{Conclusion}

In this study we examined the dividend behaviour of Indian companies. Do Indian firms follow stable dividend policies? How do the monetary policy restrictions affect the dividend payouts of the firm? We use Lintner's model to test for dividend stability of firms in India. We discard the results of the two-way fixed effects model, as it does not provide appropriate estimations in a dynamic setting. Hence we use GMM estimator, which accounts for heterogeneity and is most suitable in a dynamic setting. Our results establish the validity of the Lintner model in the emerging Indian market, and prove the underlying dynamic relationship between current dividends as dependent variable and current earnings and past dividends as independent variables. Further, our results also show that the Indian firms have lower target ratios and higher adjustment factors. This points the low smoothing and instability of dividend policies in India. The most noteworthy finding is that the restricted monetary policies have significant influence on the dividend payout behaviour of Indian firms; they cause about 5-6 percent reduction in the payout ratios. The significance of macro economic policy variable suggest that monetary restrictions do have impact on cost of raising funds and information asymmetry between lenders and borrowers increases thereby forcing the companies to reduce their dividend payout. These findings of this paper suggest that macro-economic policies have impact on corporate financing decisions. The future research should 
examine the impact of various other macro-economic policies on the corporate financing decisions of firms. 


\section{REFERENCE}

Adaoglu, Cahit (2000). "Instability in the Dividend Policy of the Istanbul Stock Exchange (ISE) Corporations: Evidence from an Emerging Market," Emerging Markets Review, 1(3), 252-270

Allen, Franklin, Antonio Bernardo and Ivo Welch (2000). "A Theory of Dividends Based on Tax Clienteles,” Journal of Finance, 55, 2499-2536.

Annuar, M.N. and Shamsher, M. (1993). "Earnings and Dividend Behaviour," Journal of Social Science and Humanities, 1(2), 171-177.

Arellanno M. and Bond, S. (1991). "Some Tests of Specification for panel Data: Monte Carlo Evidence and an Application to Employment Equations," Reviere of Economic Studies, 58, 1991, 277-97.

Arellanno, M. and Bover, O. (1995). "Another Look at the Instrumental Variables Estimation of Error Components Models,” Journal of Econometrics, 68, 1, $29-52$.

Ariff, M. and Johnson, L.W. (1994). "Securities Markets and Stock Pricing: Evidence from a Developing Market in Asia, Singapore, Sydney and London," Journal of Social Science and Humanities, 1(2), 171-177

Baker, H., Kent, G., Farrelly, E., and Richard, B. (1985). “A Survey of Management Views on Dividend Policy,” Financial Management, 78-87

Baltagi, B. H. (1995). Econometric Analysis of Panel Data, John Wiley \& Sons.

Bhat, Ramesh and Pandey, I.M. (1994). "Dividend Decision: A Study of Managers' Perceptions,” Decision, 21(1\&2), 67-86.

Black, F. (1976). “The Dividend Puzzle,” Journal of Portfolio Management, 5-8.

Brittain, J. A. (1966). Corporate Dividend Policy, Washington, D. C.: The Brookings Institution.

Chateau, J. D. (1979). "Dividend Policy Revisited: Within- and Without-of-Sample Tests,” Journal of Business Finance E Accounting, 6, 355-372.

Desai, Mihir A., C. Fritz Foley and James R. Hines Jr. 2002. "Dividend Policy inside the Firm,” NBER Working Paper No. 8698.

Deventer, K. L. and Warther, V. A. (1998). "Dividends, Asymmetric Information, and Agency Conflicts: Evidence from a Comparison of the Dividend Policies of Japanese and US Firms", Journal of Finance, 53, 879-904.

Easterbrook, Frank H. 1984. “Two Agency-Cost Explanations of Dividends,” American Economic Review, 74, 650-659. 
Fama, E. F. and Babiak, H. (1968). “Dividend Policy: An Empirical Analysis,” Journal of American Statistical Association, 1132-1161.

Gertler, Mark (1988), "Financial Structure and Aggregate Activity: An Overview," Journal of Money Credit and Banking, 20, 559-88.

Glen, J. D., Karmokolias, Y., Miller, R. R., and Shah, S. (1995). "Dividend Policy and Behaviour in Emerging Markets: To Pay or Not to Pay," IFC Discussion Paper No. 26.

Greene, W. H. (2003). Econometric Analysis, 5th edition, Singapore: Pearson Education, Pte. Ltd.

Jensen, Michael (1986). "Agency Costs of Free Cash Flow," American Economic Review, 76, 323-329.

Lasfer, M., (1996). “Taxes and Dividends: the Uk Evidence," Journal of Banking Finance, $20,455-472$.

Lehmann, Alexander and Mody, Ashok (2004). "International Dividend Repatriations," IMF Working Paper WP/04/5.

Leithmer, S. and Zimmermann, H. (1993). "Market Value and aggregate Dividends: A Reappraisal of Recent Tests, and Evidence from European Markets," Swiss Journal of Economics and Statistics, 129, 99-119.

Lintner, J. (1956). "Distribution of Incomes of Corporations Among Dividends, Retained Earnings and Taxes," American Economic Review, 97-113

McDonald, J., Jacquillant, B., and Nussenbaum, M., (1975). "Dividend, Investment and Financing Decisions: Empirical Evidence on French Firms," Journal of Financial and Quantitative Analysis, 10, 741-755.

Miller, M. and Modgliani, F. (1961). "Dividend Policy, Growth and the Valuation of Shares," Journal of Business, 411-433.

Pandey, I. M. (2003). "Corporate Dividend Policy and Behaviour: The Malaysian Evidence," Asian Academy of Management Journal, vol. 8, no. 1, 17-32.

Pettit, P.R. (1977). “Taxes, Transactions Costs and Clientele Effects of Dividends," Journal of Financial Economics, 419-436.

Pindyck, Robert S. and Rubinfeld, Daniel L. (1998). Econometrics Models and Economic Forecasts, $4^{\text {th }}$ Edition, Singapore: McGraw Hill International Edition.

Pruitt, S.W. and Gitman, L.J. (1991). "The Interactions between the Investment, Financing, and Dividend Decisions of Major U. S. Firms," Finance Review, 26, 409-430.

Shevlin, T., (1982). "Australian Corporate Dividend Policy: Empirical Analysis," Accounting and Finance, 1-22. 
Shleifer, A. and Vishny, R. (1986). "Large shareholders and corporate control," Journal of Political Economy, 94, 461-488.

Stiglitz, Joseph (1992). "Capital Markets and Economic Fluctuations in Capitalist Economies," European Economic Reviere, 36, 269-306. 